
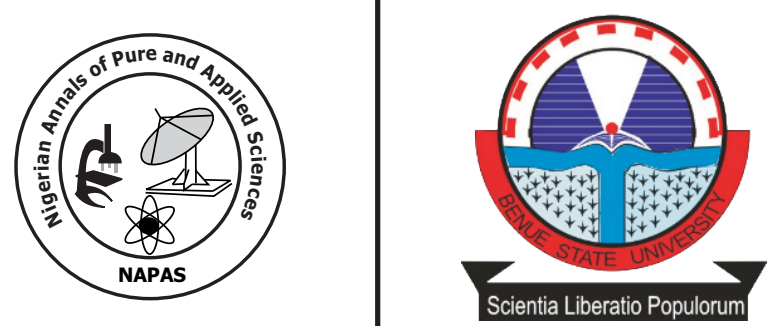

\title{
Optimising Soymilk Protein Nutriture through Selection of Appropriate Processing Technique
}

\author{
Ogo, A.0. ${ }^{{ }^{*}}$, Amali, E.0.0. ${ }^{1}$, Efiong, E.E. ${ }^{2}$, Gbaa, A $^{3}$, and Enenche, $D^{3}$. \\ ${ }^{1}$ Department of Biochemistry, Benue State University, Makurdi, Nigeria \\ ${ }^{2}$ Department of Biochemistry, Federal University Lafia, Nasarawa State \\ ${ }^{1}$ Centre for Food Technology and Research, Department of Chemistry, \\ Benue State University, Makurdi, Nigeria \\ *Corresponding author:oogo@bsum.edu.ng
}

\begin{abstract}
A significant contributor to compromised nutriture of a particular nutrient is the method of processing or preparation. The pre-treatment technique employed in the processing of soybean milk is a wellrecognized factor that not only aids in the deactivation of certain anti-nutritional components but also enhances its protein digestibility and bioavailability. Second to the overall importance of soybean is the protein composition, which is a function of the monomeric amino acid it contains. Thus, the amino acid profile of soybean milk processed by three pretreatment methods including soaking, roasting and boiling was analyzed using amino acid analyzer (model 120A PTH; Applied Biosystems, Thermo Fisher Scientific, USA). The results show that pretreatment by boiling retained the best product judged in terms of general nutritional quality as shown by higher total amino acid content recorded as $97.95 \mathrm{~g} / 100 \mathrm{~g}$ compared to those of toasted and soaking which were $88.36 \mathrm{~g} / 100 \mathrm{~g}$ and $91.28 \mathrm{~g} / 100 \mathrm{~g}$ respectively. Also boiling technique recorded the highest total essential amino acid content of $51.01 \mathrm{~g} / 100 \mathrm{~g}$ as against $46.58 \mathrm{~g} / 100 \mathrm{~g}$ and $45.85 \mathrm{~g} / 100 \mathrm{~g}$ for toasting and soaking methods employed. In the same vein, boiling technique gave the highest amount of total conditional amino acids, which was $46.37 \mathrm{~g} / 100 \mathrm{~g}$ when compared to that of toasting at $43.18 \mathrm{~g} / 100 \mathrm{~g}$ ) and soaking at $42.26 \mathrm{~g} / 100 \mathrm{~g}$, making it ideal for therapeutic purposes. This findings show that soymilk produced through boiling pretreatment is recommended for consumption at both household and commercial levels in order to optimize the full benefit of soymilk nutrition and therapeutics.
\end{abstract}

Key word: Amino acids, processing technique, Soya milk, Nutritional quality. 


\section{Introduction}

The soybean (Glycine max) is a legume species native to East Asia. It is widely grown for its edible bean which has numerous uses (USDA, 2000). According to report by United States Development Agency, consumption of soybean is on the increase making it the World's fourth most important crop, only surpassed by wheat, maize and rice (USDA, 2011). Food products derived from soybean include but not limited to no fermented and non-fermented oriental soy foods such as tofu, okara, roasted soy nuts or flour, yuba, (Gao et al., 2011). Among these, soymilk has become widely acceptable as a nutritionally balanced refreshing drink (Parsons et al., 2000). A number of reports have highlighted the health benefits of soy proteins contained in the milk product as it relates reduction of cholesterol levels and menopause symptoms and the reduction of the risk for several chronic diseases such as cancer, heart disease, and osteoporosis

(Asbridge et al., 1995 and Lee et al. (2007)). It is even recommended that a daily intake of 2050 grams of isolated soymilk protein could result in a $20-30 \%$ reduction in the risk of coronary diseases (Touba et al., 2011).

It has been documented that soybeans contain numerous anti-nutritional factors such as trypsin inhibitors (Asbridge et al., 1995), which inhibit absorption of the beneficial components like proteins (Lokuruka, 2011). Interestingly though, actions of trypsin inhibitors can be controlled or their activity inactivated by a reasonable amount of heat (Mateos-aparicio et al., 2008). A plethora of factors contribute to variation and quality of proteins found in soybean products among which are insufficient or excessive heat during processing (Parsons et al., 2000; TundeAkintunde, \& Souley, 2009). Research on soymilk and essential amino acids in soybean milk has received little attention, while the majority of the results reported to date relate to isolated soy protein systems, which differ considerably from soymilk (Kwok \& Niranjan, 1995). It has been established that during the making of soymilk, the heat-induced denaturation of soy proteins causes the rearrangement and association of protein subunits to form soluble aggregates, which may not be bioavailable (Malaki et al., 2008; Kwok \& Niranjan, 1995). The extent of this aggregation and how a particular processing technique promotes this process is largely a subject of further research in food and nutrition science. The full benefits of soymilk diet, and in particular, soymilk has not been fully optimized owing to reduction in the nutritional quality occasioned by inappropriate handling and/or method of preparation, which impacts on the content and quality of its nutritional component. Hence, a good understanding of the nutritional assessment of essential amino acids, which are the drivers of the functions of proteins in soybean milk production using different techniques is imperative in order to maximize its nutritional benefits.

\section{Materials and Methods}

\section{Collection and preparation of Soybean Samples}

Soybean used for the work was purchased from Modern Market Makurdi, in Benue State, Nigeria. Three kilogram $(3 \mathrm{Kg})$ of soybean seeds were sorted by hand and then cleaned in order to remove dirt and other impurities like foreign seeds and seed stalk. This was divided equally and three pretreatment methods namely boiling, soaking and drying were then used for the production of soymilk.

\section{Preparation of Soybean Milk by Boiling Extraction}

The beans were blanched in hot water for 5 min to soften the seeds and aid in seed coat removal, to reduce the beany flavour and to eliminate some anti-nutritional factors. The beans were washed and dried then milled into powdered form. The soybean flour was then filtered using sieve before further processing into milk.

\section{Preparation of Soybean Milk by Soaking Extraction}

The beans were first warm washed and water was then added to it in the ratio of $1: 3$ (beans to water) and then allowed to soak for $3 \mathrm{~h}$ under room temperature. The soybeans were then dehulled and the chaff removed by adding water and decanting. Milling was done using a Kenwood blender. About 3 parts of water was added to the slurry and the mixture was allowed to boil on fire for about $15 \mathrm{~min}$ before being bottled.

\section{Preparation of Soybeans Milk by Frying Extraction}

The soybeans was washed and put into a pot with a low flame of fire and allowed to toast for about $45 \mathrm{~min}$ to $1 \mathrm{~h}$. The seed coats were then removed before milling was done using a mechanical grinder. It was then sieved and packaged for further use.

\section{Nitrogen Determination}

Two hundred milligram (200 mg) of ground sample was weighed, wrapped in Whatman No. 1 filter paper and put in a Kjeldahl digestion flask. $10 \mathrm{ml}$ concentrated sulphuric acid was added 
followed by a $0.5 \mathrm{~g}$ catalyst mixture of sodium sulphate $\left(\mathrm{Na}_{2} \mathrm{SO}_{4}\right)$, copper sulphate $\left(\mathrm{CuSO}_{4}\right)$ and selenium oxide $\left(\mathrm{SeO}_{2}\right)$ in the ratio 10:5:1 to facilitate digestion together with four pieces of anti-bumping granules. The flask was then put in Kjeldhal digestion apparatus for $3 \mathrm{~h}$ until the liquid turned light green. The digested sample was cooled and diluted with distilled water to $100 \mathrm{ml}$ in a standard volumetric flask. Ten milliliter $(10 \mathrm{ml})$ aliquot of the diluted solution with $10 \mathrm{ml}$ of $45 \%$ sodium hydroxide was put into a Markham distillation apparatus and distilled into $10 \mathrm{ml}$ of $2 \%$ boric acid containing 4 drops of bromocresol green/methyl red indicator until about $70 \mathrm{ml}$ of distillate was collected. The distillate was then titrated with standardized $0.01 \mathrm{~N}$ hydrochloric acid to grey coloured end point. The percentage nitrogen was calculated thus:

$$
\text { Percentage Nitrogen }=\frac{(a-b) \times 14 \times v \times 100}{W \times C}
$$

\section{Where:}

$\begin{array}{lll}\mathbf{A} & = & \text { Titre value of digested sample } \\ \mathbf{b} & = & \text { Titre value of blank sample } \\ \mathbf{v} & = & \text { volume after dilution }(100 \mathrm{ml}) \\ \mathbf{W} & = & \text { weight of dried sample }(\mathrm{in} \mathrm{mg}) \\ \mathbf{C} & = & \text { Aliquot of sample used }(10 \mathrm{ml})\end{array}$

\section{Determination of Amino Acid Profile Determination of Tryptophan}

Tryptophan is susceptible to acid hydrolysis, thus it was separately determined by using thioglycolic acid with $6 \mathrm{~N}$ hydrochloric acid to preserve it. Tryptophan in the sample was hydrolyzed with $4.2 \mathrm{M}$ sodium hydroxide. The mixture was dried and $1 \mathrm{~g}$ weighed into an extraction thimble where a 2:1 mixture of chloroform/methanol was used to de-fat the sample in a soxhlet apparatus for $15 \mathrm{~h}$ as described by AOAC, 2005. Thereafter, $60 \mu \mathrm{L}$ of the defatted sample was then weighed into a glass ampoule and $10 \mathrm{ml}$ of $4.2 \mathrm{M} \mathrm{NaOH}$ was added and oxygen expelled from it by passing nitrogen into the ampoule. The glass ampoule was then sealed with Bunsen burner flame and put in an oven preset at $105^{\circ} \mathrm{C}$ for 22 hours. The ampoule was allowed to cool before being broken open at the tip and the content filtered to remove the humins. The filtrate was neutralized with $6 \mathrm{~N} \mathrm{HCl}$ and evaporated to dryness at $40^{\circ} \mathrm{C}$ under vacuum in a rotary evaporator. The residue was dissolved with $5 \mathrm{ml}$ of acetate buffer of $\mathrm{pH} 7$ before being stored in plastic specimen bottles. Then $10 \mu \mathrm{L}$ aliquot of the preparation was loaded into the cartridge of sequential multi-sampler amino acid analyzer (model120A PTH). The peak area which corresponds to the concentration of tryptophan amino acid was calculated from the integrator attached to the analyzer. The concentration of tryptophan is calculated per $100 \mathrm{~g}$ protein as follows:

Concentration $(\mathrm{g} / 100 \mathrm{~g}$ protein $)=\mathrm{NH} \times$ width $@ \frac{\mathrm{NH}}{2} \times \mathrm{Std} \times \mathrm{C}$

Where $\mathbf{C}=\frac{\text { Dilution } \times \mathbf{1 6}}{\text { Sample Wt }(\mathrm{g}) \times \mathrm{N} \% \times \text { vol.loaded }} \div \mathrm{NH} \times \mathrm{W}($ nleu $)$

$\mathbf{S}_{\text {std }}=\mathrm{NE}_{\text {std }} \times$ Mol. Weight $\times \mu \mathrm{AA}_{\text {std }}$

\section{Determination of Other Amino Acids}

The soybean sample was dried to constant weight and then defatted using chloroform/methanol mixture of ratio 2:1. About $4 \mathrm{~g}$ of the sample was put in an extraction thimble and extracted for $15 \mathrm{~h}$ in soxhlet extraction apparatus. One gramme $(1 \mathrm{~g})$ of the defatted sample was weighed into a glass ampoule and $7 \mathrm{ml}$ of $6 \mathrm{~N} \mathrm{HCl}$ was added and oxygen expelled by passing nitrogen into the ampoule to avoid possible oxidation of sulphur-containing amino acids including methionine and cysteine. The glass ampoule was then sealed with Bunsen burner flame and put in an oven preset at $105^{\circ} \mathrm{C}$ for $22 \mathrm{~h}$. The ampoule was allowed to cool before being broken open at the tip and the content filtered to remove the humins. The filtrate was then evaporated to dryness using rotary evaporator and the residue dissolved with $5 \mathrm{ml}$ acetate buffer of $\mathrm{pH} 2$ before being cooled. Then $60 \mu \mathrm{L}$ of the preparation mixture was dispensed into the cartridge of the amino acid analyzer, which is designed to separate and analyze free acidic, neutral and basic acids of the hydrolysate. The peak area which corresponds to the concentration of each amino acid was calculated from the integrator attached to the analyzer as follows:

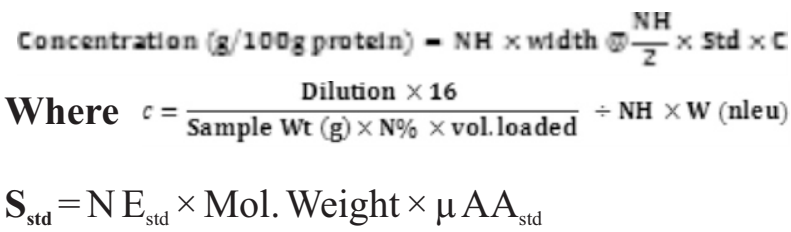

\section{Results}


Table 1: Overview of amino acid profile of soymilk processed by toasting, boiling and soaking methods.

\begin{tabular}{llll}
\hline Amino acid & $\begin{array}{l}\text { Toasted } \\
\mathbf{( g / 1 0 0 g} \text { protein) }\end{array}$ & $\begin{array}{l}\text { Boiled } \\
\mathbf{( g / 1 0 0 g} \text { protein })\end{array}$ & $\begin{array}{l}\text { Soaked } \\
\mathbf{( g / 1 0 0 g} \text { protein })\end{array}$ \\
\hline Leucine & $9.05 \pm 0.12^{\mathrm{b}}$ & $11.71 \pm 0.02^{\mathrm{a}}$ & $9.60 \pm 0.11^{\mathrm{b}}$ \\
Lysine & $8.44 \pm 0.13^{\mathrm{b}}$ & $10.68 \pm 0.22^{\mathrm{a}}$ & $8.40 \pm 0.2^{\mathrm{b}}$ \\
Isoleucine & $7.10 \pm 0.07^{\mathrm{b}}$ & $10.65 \pm 0.01^{\mathrm{a}}$ & $8.65 \pm 0.04^{\mathrm{b}}$ \\
Phenylalanine & $5.67 \pm 0.10^{\mathrm{c}}$ & $5.58 \pm 0.12^{\mathrm{c}}$ & $5.60 \pm 0.2^{\mathrm{c}}$ \\
Tryptophan & $8.79 \pm 0.01^{\mathrm{b}}$ & $10.91 \pm 0.2^{\mathrm{a}}$ & $9.20 \pm 0.12^{\mathrm{a}}$ \\
Valine & $7.99 \pm 0.10^{\mathrm{b}}$ & $9.38 \pm 0.11^{\mathrm{a}}$ & $7.60 \pm 0.12^{\mathrm{b}}$ \\
Methionine & $5.28 \pm 0.03^{\mathrm{b}}$ & $8.15 \pm 0.08^{\mathrm{a}}$ & $5.10 \pm 0.2^{\mathrm{b}}$ \\
Proline & $6.25 \pm 0.01^{\mathrm{c}}$ & $8.14 \pm 0.10^{\mathrm{a}}$ & $6.94 \pm 0.11^{\mathrm{c}}$ \\
Arginine & $9.60 \pm 0.2^{\mathrm{a}}$ & $13.31 \pm 0.2^{\mathrm{a}}$ & $10.70 \pm 0.2^{\mathrm{a}}$ \\
Tyrosine & $8.44 \pm 0.03^{\mathrm{c}}$ & $12.69 \pm 0.13^{\mathrm{a}}$ & $8.70 \pm 0.05^{\mathrm{b}}$ \\
Histidine & $6.26 \pm 0.05^{\mathrm{b}}$ & $9.16 \pm 0.02^{\mathrm{a}}$ & $6.30 \pm 0.01^{\mathrm{b}}$ \\
Cysteine & $4.78 \pm 0.13^{\mathrm{c}}$ & $8.90 \pm 0.10^{\mathrm{a}}$ & $5.70 \pm 0.11^{\mathrm{b}}$ \\
Alanine & $3.90 \pm 0.2^{\mathrm{a}}$ & $4.47 \pm 0.2^{\mathrm{b}}$ & $4.43 \pm 0.01^{\mathrm{b}}$ \\
Glutamic acid & $11.87 \pm 0.02^{\mathrm{a}}$ & $9.96 \pm 0.12^{\mathrm{a}}$ & $10.59 \pm 0.2^{\mathrm{a}}$ \\
Glycine & $4.80 \pm 0.05^{\mathrm{a}}$ & $6.63 \pm 0.03^{\mathrm{b}}$ & $4.61 \pm 0.07^{\mathrm{a}}$ \\
Threonine & $8.30 \pm 0.04^{\mathrm{b}}$ & $10.49 \pm 0.03^{\mathrm{a}}$ & $8.90 \pm 0.12^{\mathrm{c}}$ \\
Serine & $4.24 \pm 0.01^{\mathrm{d}}$ & $4.64 \pm 0.03^{\mathrm{d}}$ & $3.83 \pm 0.01^{\mathrm{d}}$ \\
Aspartic acid & $10.70 \pm 0.10^{\mathrm{a}}$ & $10.61 \pm 0.03^{\mathrm{a}}$ & $9.74 \pm 0.11^{\mathrm{a}}$ \\
Glutamine & $6.77 \pm 0.04^{\mathrm{b}}$ & $9.84 \pm 0.06^{\mathrm{a}}$ & $7.66 \pm 0.10^{\mathrm{b}}$ \\
\hline
\end{tabular}

Values are mean \pm standard error of the mean (SEM) for duplicate measurement $\mathrm{s}$. Means with different superscripts within a row are significantly different at $\mathrm{p}<0.05$ by GraphPad Prism

Table 2: Overview of categories of amino acids in soymilk processed by toasting, boiling a nd soaking pretreatment methods.

\begin{tabular}{llll}
\hline Category & $\begin{array}{l}\text { Toasted } \\
(\mathbf{g} / \mathbf{1 0 0 g} \text { protein) }\end{array}$ & $\begin{array}{l}\text { Boiled } \\
(\mathbf{g} / \mathbf{1 0 0 g} \text { protein })\end{array}$ & $\begin{array}{l}\text { Soaked } \\
\mathbf{( g / 1 0 0 g} \text { protein })\end{array}$ \\
\hline TAA & $88.36 \pm 0.07^{\mathrm{c}}$ & $97.95 \pm 0.11^{\mathrm{a}}$ & $91.28 \pm 0.02^{\mathrm{b}}$ \\
TEAA & $40.58 \pm 0.10^{\mathrm{b}}$ & $51.01 \pm 0.03^{\mathrm{a}}$ & $41.85 \pm 0.10^{\mathrm{b}}$ \\
TCAA & $43.18 \pm 0.03^{\mathrm{b}}$ & $46.37 \pm 0.05^{\mathrm{a}}$ & $42.26 \pm 0.03^{\mathrm{b}}$ \\
TNEAA & $14.6 \pm 0.02^{\mathrm{b}}$ & $21.57 \pm 0.13^{\mathrm{a}}$ & $15.17 \pm 0.04^{\mathrm{c}}$ \\
\hline
\end{tabular}

Values are mean \pm standard err or of the mean (SEM) for duplicate measurements. Means with different superscripts within a row are significantly different at $\mathrm{p}<0.05$ by GraphPad Prism

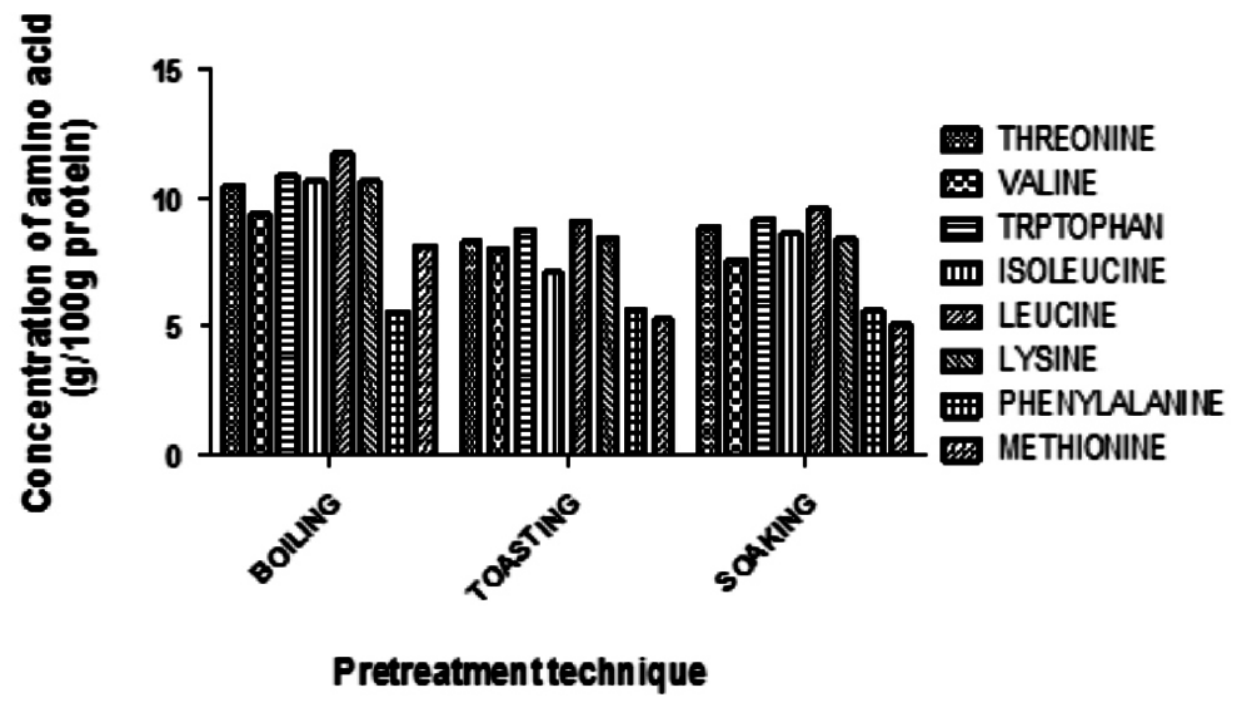

Figure 1: Comparison of essential amino acid in soymilk produced through pretreated by boiling, toasting and soaking 


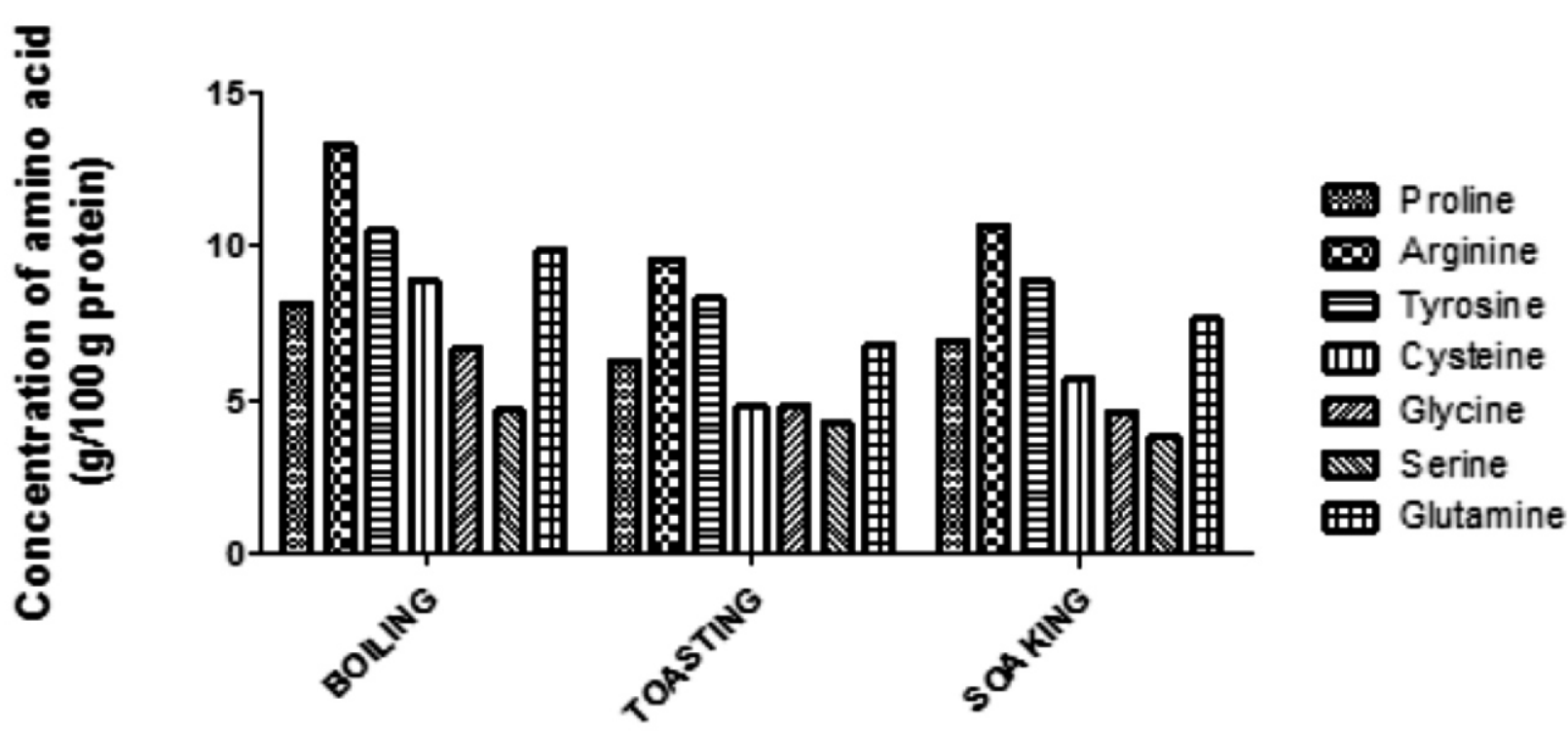

\section{Pretreatment technique}

Figure 2: Comparison of conditionally essential amino acid in soymilk produced through pretreated by boiling, toasting and soaking

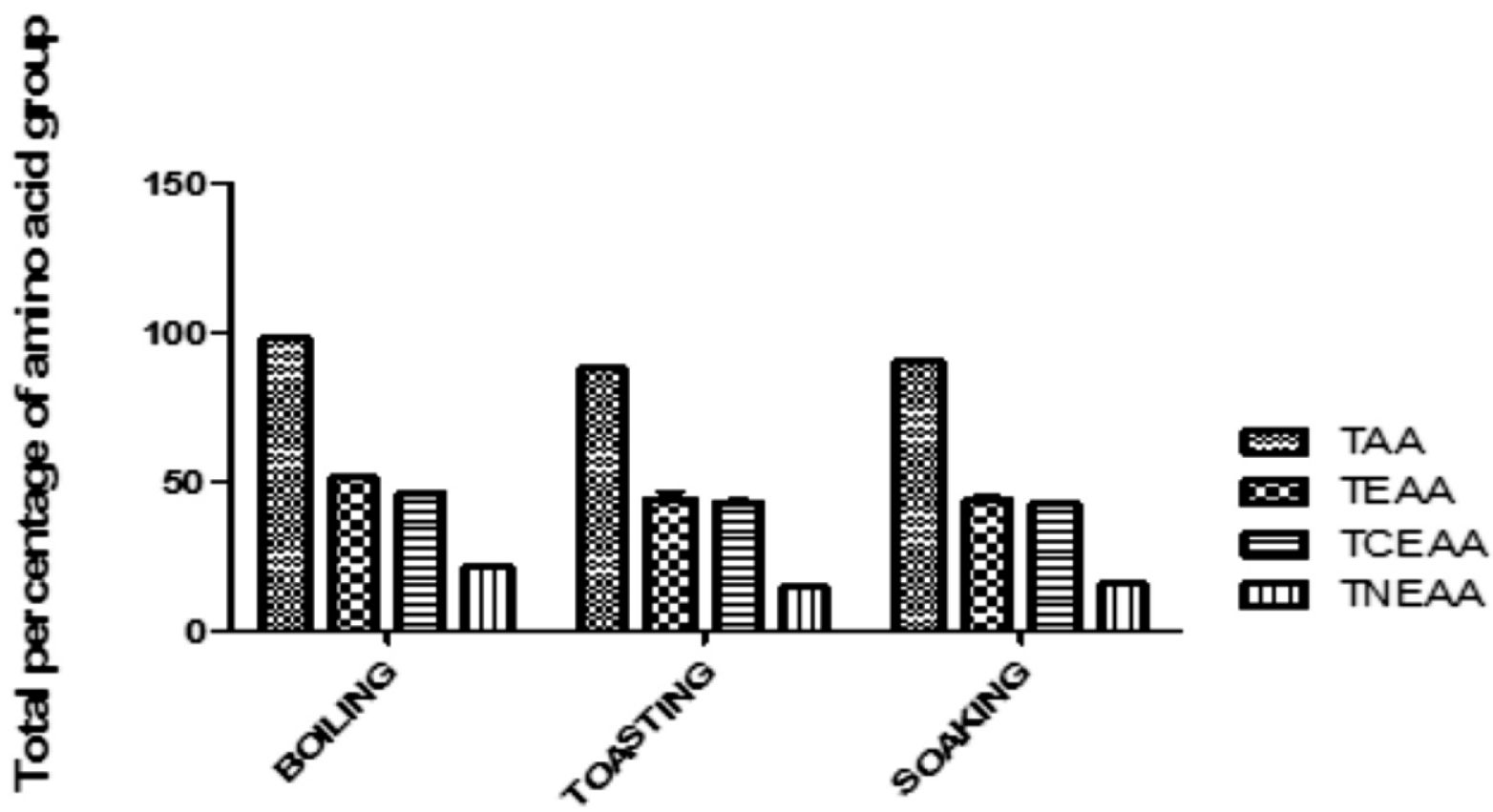

\section{Pretreatment technique}

Figure 3: Comparison of the percentage of total amino acid group in soyamilk produced through pretreated by boiling, toasting and soaking. Values are mean \pm standard error of the mean (SEM) for duplicate measurements.

\section{Discussion}

The results of the amino acid content of soymilk produced by using three different methods of pretreatments is shown in table 1. In general, it can be seen that soymilk provide a good number of amino acid, however, there is variation in the amount of different amino acids influenced by the method of pretreatment. Soymilk processed by boiling contain more of the essential amino acids representing more than half of the total amino acid content of the samples when compared with the other methods of toasting and soaking, suggesting that this pretreatment method retained more of this monomeric units of proteins as the effect of temperature only had minimal impact on the nutritional content. This result agrees with that reported by Ikya and coworkers, who obtained higher protein value for soymilk through boiling (Ikya et al, 2015). It is important to note that leucine is the most concentrated essential amino acid found in this study with values ranging from 9 to about $12 \mathrm{~g} / 100 \mathrm{~g}$ protein. This result is in 
consonance with those reported in a study that assessed essential amino acid profile of different soy products (Kumar et al., 2016). Intriguingly however, one of the essential amino acids, phenylalanine showed no significant difference ( $p$ $<0.05$ ) among the different methods of pretreatment and its value is lower when compared to other amino acid in the same class of nutritional relevance. This observation may be relevant to nutritional advice in terms of addressing patients with conditions such as phenylketonuria, whose solution appears to be consumption of food low in this amino acid in what is termed as dietary restriction. Also soymilk can supply a reasonable amount of conditionally essential amino acids, which may be required at certain periods such as growth for children, pregnancy and in conditions requiring tissue repairs. In this regard, supplementing diets with soymilk pretreated by boiling, which comparatively gave the highest amount may be helpful in this situation.

Several reports agree that applying heat with temperature above $100^{\circ} \mathrm{C}$ in the preparation of soybean products not only inactivate trypsin inhibitors, but can also denature soy proteins resulting in amino acid degradation (Murugkar et al., 2015). This is evident in general reduction in the amount of amino acids found in the present study when compared to previous reports (Ikya et al, 2015; Onuora et al., 2007). However, the boiling method of pretreatment gave a significant higher amounts when compared to values obtained using the other two methods, which agrees with results of previous work (Rosy et al., 2014). Thus brief boiling before production of soymilk appears to preserve more nutritional quality of the drink in terms of general amino acid, and in of the essential ones in particular. Worthy of note is the high amount of glutamic acid and glutamine (among the class of nonessential amino acids) found across all the three pretreatment methods, which agrees with similar study that surveyed the amount of essential and nonessential amino acids of soybeans collected from different State of Brazil (Goldflus et al., 2005). Glutamine found in boiling pretreatment is significantly higher $(p<0.05)$ than the other two methods, consumption of this product is recommended for athletes and other body builders to enable them keep fit. It is known that glutamine rapidly depletes during muscular exercise by muscle cells thus, consumption of soymilk may be a good substitute for continuous supply of the glutamine/glutamic acid pair. It should be cautioned however that, documented evidence suggest that glutamic acid can stimulate the brain's glutamate receptors, linking this to some types of epilepsy (reviewed by Brain Meldrum, 2000). It is therefore advisable that people with such conditions should abstain or consume products derived from soybeans such as soymilk, which this study found high levels but intriguingly the boiling pretreatment method gave lower amounts, making it tolerable if complete abstinence is impossible. Another nonessential amino acid found in high amount is aspartic acid. Few studies have revealed some evidence supporting the boosting ability of this amino acid on testosterone, recommending its supplementation for people with cases of infertility (D'Aniello et al., 1996 and Topo et al., 2009). However, further detailed research including clinical trials are required to leverage on this suggestion.

\section{Conclusion}

The study shows that Soymilk prepared by different processing methods including toasting, boiling and soaking contain a reasonable amount of amino acids, agreeing with previous documented reports on amino acid composition of soymilk, as none of the processing methods showed a complete loss of any amino acid. However, amino acid composition of the soybean products is seen to be strongly affected by the processing conditions and behaves differently according to the processing methods employed but with comparative higher values recorded for boiling pretreatment. Thus consumption of soymilk particularly that which is processed by boiling pretreatment is recommended to combat protein malnutrition. Similarly, the retention of higher amounts of conditionally essential amino acids make this product ideal for therapeutic purposes. Further research would be required to apply these products to experimental animals in order to determine their digestibility ratios as a means of assessing their nutritional value suggestive of their incorporation into cellular protein repertoire.

\section{References}

Asbridge, D.A. (1995). Soybeans vs. other vegetable oils as a source of edible oil products. In Practical Handbook of Soybean Processing and Utilization, D.R. Erickson (Ed.), AOCS Press, Champaign, IL, 1-8

Brain S. M. (2000). Glutamate as a neurotransmitter in the Brain: Review of physiology and Pathology. The Journal of Nutrition.130 (4); 1007S-1015S

D'Aniello A, Di Cosmo A, Di Cristo C, Annuziato L, Petrucelli L and Fisher G (1996) Involvement of D-aspartic acid in the 
synthesis testosterone in rat testes. Life Sci. 59(2); 97-104

Goldflus F, Ceccantini M and Santos W (2006) Amino Acid Content of Soybean Samples Collected in Different Brazilian States Harvest 2003/2004. Brazilian Journal of Poultry 8 (2) 105-111)

Gao, X., Cui, C. and Ren, J. (2011). Changes in the chemical composition of traditional Chinese-type soy sauce at different stages of manufacture and its relation to taste. International Journal of Food Science and Technology, 46, 243-249.

J.K. Ikya, D.I. Gernah, H.E. Ojobo and O.K. Oni (2015). Effect of Cooking Temperature on Some Quality Characteristics of Soy Milk

Kwok, K. C. and Niranjan, K. (1995). Review: effect of thermal processing on soymilk. International Journal of Food Science \& Technology, 30: 263-295. Advance Journal of Food Science and Technology 5(5): 543 546.

Lee, Y. W., Kim, J. D., Zheng, J. Z., and Row, K. H. (2007). Comparisons of isoflavones from Korean and Chinese soybean and processed products. Biochemical Engineering Journal, 36, 49-53.

Lokuruka MNI (2011) Effects of Processing on Soybean Nutrients and Potential Impact on Consumer Health: An Overview. African Journal of Food, Agriculture, Nutrition and Development Vol.11 Num 4; 1-12

Malaki, N.A., Tosh, S., Poysa, V., Woodrow, L., and Corredig, M. (2008). Physicochemical characterization of soymilk after step-wise centrifugation. Food Research International, 41;286-294.

Mateos-aparicio, I., Redondo C.A., Villanueva-suárez, M.J., Zapata- Revilla, M.A. (2008). Soybean, a promising health source. NutriciónHospitalaria, 23, 305312.

Onuora, C. E, Adejare, A.O. and Uhiara, N.S. (2007). Comparative physico-chemical evaluation of soymilk and soya cake produced by three different methods. Nigerian Food JournaL,Vol. 25,No. 2; 28 38

Parsons, C.M., Zhang, Y. and Araba, M. (2000). Nutritional evaluation of soybean meals varying in oligosaccharide content. Poultry Science, 79, 1127-1131.

Rosy, B. and Manpreet K. (2014). Quality improvement and sensory evaluation of soya milk prepared by germinated soybeans. International Journal of Food And Nutritional Sciences, 3(6); 136-144.

Topo E, Soricell A, D'Aniello A, Ronsini S and D'Aniello G (2009). The role and molecular mechanism of D-aspartic acid in the release and synthesis of LH and testosterone in humans and rats. Reprod Biol Endocrinol 27 (7); 110-120.

Touba, I., Zahra, I., Mostafa, M., Mandana, A., Mohammad, Z. and Mohammad, A.S. (2011). Investigation of Optimized Methods for Improvement of Organoleptical and Physical Properties of Soy milk.International Journal of Farming and Allied Sciences, 2 (10): 245-250.

Tunde-Akintunde, T.Y and A. Souley, (2009). Effect of processing methods on quality of soymilk. Pakistan journal of Nutrition, 8, 1156-1158.

Vineet Kumar, Anita Rani, Lulua Hussain (2016). Essential amino acid profile of differentially processed soy products and their efficiency in meeting daily requirements. Nutrition \& Food Science, 46(2); 273-245 